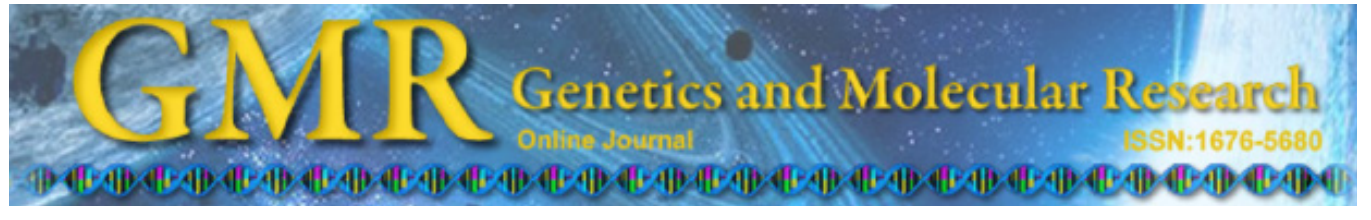

\title{
Revisiting the Brazilian scenario of registry and protection of cultivars: an analysis of the period from 1998 to 2010, its dynamics and legal observations
}

C.D. Marinho ${ }^{1}$, F.J.O. Martins ${ }^{2}$, S.C.S. Amaral ${ }^{3}$, A.T. Amaral Júnior ${ }^{1}$ L.S.A. Gonçalves ${ }^{1}$ and M.P. de Mello ${ }^{3}$

${ }^{1}$ Universidade Estadual do Norte Fluminense Darcy Ribeiro, Campos dos Goytacazes, RJ, Brasil

${ }^{2}$ Universidade Federal de Viçosa, Viçosa, MG, Brasil

${ }^{3}$ Universidade Federal Fluminense, Niterói, RJ, Brasil

Corresponding author: A.T. Amaral Júnior

E-mail: amaraljr@uenf.br

Genet. Mol. Res. 10 (2): 792-809 (2011)

Received January 17, 2011

Accepted January 24, 2011

Published May 3, 2011

DOI 10.4238/vol10-2gmr1271

\begin{abstract}
During the last 20 years, the national production of grains has increased $156.1 \%$; productivity increased $93.8 \%$ and there has been an increase of $29.1 \%$ in cultivated area. Currently, agribusiness is responsible for $40 \%$ of Brazilian exports. Nevertheless, there is little quantitative information on the main plant species of economic interest that have been registered and protected in the Agriculture, Fisheries and Food Supply Ministry (MAPA) by public and private companies, as well as by public-private partnerships. Consequently, we investigated the registry and protection of 27 species of economic interest, including the 15 that are the basis of the Brazilian diet, based on the information available on the site CultivarWeb, of MAPA, for the period from 1998 to August 30, 2010. We also examined the legislation that regulates registration and protection procedures and its implications for plant breeding and plant product development. It was found
\end{abstract}


that the private sector controls $73.1 \%$ of the registrations and $53.56 \%$ of the protections, while $10.73 \%$ of the protections were of material developed overseas. Public-private partnerships contributed little to the development of new cultivars, with $0.5 \%$ of the registries and $3.61 \%$ of the protections. We conclude that plant protection directed private investment to development of wheat and rice varieties, with the greatest public investments directed to corn and sorghum. After the Cultivar Protection Law was implemented, there was restriction of access to germplasm banks, which could inhibit advances in Brazilian plant breeding programs, indicating a need for revision of this legal barrier.

Key words: Plant breeding; Agribusiness; Registry; Protection; Public-private partnership

\section{INTRODUCTION}

A study published by the World Trade Organization (WTO) revealed that in 2009 Brazil was one of the three largest agricultural exporters in the world, following the USA and the European Union (ISTOÉ, 2010). In 2009, the value of Brazilian Agribusiness exports reached US\$64.7 billion (MDIC, 2010). Various natural conditions favor this scenario, including a diversity of climates, regular rainfall, abundant solar energy and almost $13 \%$ of all the available freshwater on the planet (Lourenço and Lima, 2009). Brazil has an arable area of 340 million hectares, of which only 63 million are currently cultivated, while 200 million hectares are used for pasture. Approximately 77 million hectares of new arable land are available for cultivation, without the need to devastate ecosystems, which is relevant for the maintenance of biodiversity. This is especially important for a country that has the largest forest reserve on the planet.

The increases in productivity in agriculture in the country were reached and tend to evolve due mostly to the registration and recommendation of new varieties by plant breeders (Rodrigues, 2006; Tollefson, 2010; Wilkinson, 2010).

From 2006 to 2009, the mean rate of increase in national grain production (rice, beans, corn, soybeans, and wheat) was $4.7 \%$ per year, reaching 141.9 million tons in August 2010, of which 77.38\% was destined for internal consumption (CONAB, 2010). Estimates in August 2010 indicated a production of 148 million tons of cereals, legumes and oil crops, with 46.7 million hectares under cultivation. Three cultures accounted for $91 \%$ of the production of this group and occupied $83.4 \%$ of the cultivated area, these being rice, corn and soybeans (IBGE, 2010). During the last 20 years, national grain production increased $156.1 \%$, productivity increased $93.8 \%$, and the cultivated area increased 29.1\% (CONAB, 2010), which demonstrates that agribusiness has evolved in a planned manner and is ever more committed to sustained management and protection of biodiversity.

Currently, Brazilian agribusiness is responsible for $40 \%$ of the country's exports. Beginning in the 1990s, Brazil rapidly graduated from importer to exporter of various agricultural products, especially for species that are not originally from this country. Products made from soybean, sugarcane, tobacco, cotton, other plants that produce textile fibers, fruit, and their derivatives, as well as vegetables and cereals, are major Brazilian export products. The grains and derivatives of soybeans and coffee, as well as tobacco leaves and two products made from 
sugarcane (alcohol and sugar), account for about 50\% of agribusiness exports (MDIC, 2010).

Given this information, there are fundamental questions that need to be answered in order to comprehend the advances that have occurred in Brazilian agribusiness. One of these questions involves the participation of public and private institutions responsible for the registration, protection and recommendation of highly productive cultivars. Another concern of great importance is to know whether among the species responsible for advances in national agribusiness, and also those of major importance for the Brazilian diet, there has been participation by Brazilian companies in plant breeding efforts that have culminated in registration and protection in the Agriculture, Fisheries and Food Supply Ministry (MAPA, 2010). There are gaps in the information concerning the important role of Brazil in world agribusiness, especially concerning the institutions that produced the varieties that "redesigned" Brazilian agriculture.

These concerns bring to light the necessity to better understand whether the progress in Brazilian agriculture was due to plant breeders in the public or private sectors, based on registration of new varieties in MAPA. Also, to what degree have public-private partnerships contributed to the advancement of Brazilian agriculture?

In planning the scope of our study, we considered the following crops: wheat, rice, corn, sorghum, barley, oats, soybeans, beans, peanuts, sugarcane, cotton, coffee, tobacco, cassava, potatoes, lettuce, carrots, tomatoes, beets, sweet potatoes, pepper, apples, grapes, banana, oranges, papaya, and coconut. Our objective was to make available information about the nature of the institutions that maintain cultivars, both those registered and protected, with MAPA. The period for this research was 1998 to August 30, 2010, and the information that was collected included: i) number of registrations and protections for the 27 species, ii) among these registrations and protections, the magnitude of the participation of the private, public and public-private (partnership) sectors. We also examined the laws and decrees that regulate the procedures for registration and protection, made an analysis of the institutions that obtained these registrations and protections, and based on this information, studied and made inferences about the national scenario of plant breeding and plant product development.

\section{MATERIAL AND METHODS}

The data for this study were obtained from the national cultivar registry data bank (RNC) and the national service for the protection of cultivars (SNPC), denominated CultivarWeb, available in real time on the website of the MAPA.

We grouped the registrations and protections according to the nature of the institutions that obtained them, separated into private institution, public institution and public-private partnerships. The information was entered into tables and analyzed using Microsoft Office Excel 2007 , and the data were presented using descriptive statistics.

To select the species for inclusion in this study, we took into account their importance economically and as food. According to Paterniani (1998), confirmed by Pinto (2009), only 30 plant species effectively feed the world, and only 15 (rice, wheat, corn, sorghum, barley, sugarcane, beets, potato, sweet potato, cassava, dry beans, soybeans, peanuts, coconut, and banana) constitute $90 \%$ of the Brazilian diet.

Consequently, the species that were considered were: wheat (Triticum aestivum L.); rice (Oryza sativa L.); common corn (Zea mays L.); sorghum (Sorghum spp); barley (Hordeum vulgare L.); oats (Avena spp); soybean (Glycine max (L.) Merr.); common bean (Phaseo- 
lus vulgaris L.); peanuts (Arachis hypogaea L.); sugarcane (Saccharum spp); cotton (Gossypium spp); coffee (Coffea spp); tobacco (Nicotiana tabacum L.); cassava (Manihot esculenta Crantz); potato (Solanum tuberosum L.); lettuce (Lactuca sativa L.); carrot (Daucus carota L.); tomato (Lycopersicon esculentum Mill. = Lycopersicon lycopersicum (L.) H. Karst.); beet (Beta vulgaris L.); seet potato (Ipomea batatas (L.) Lam.); pepper (Capsicum spp); apple (Malus spp); grapes (Vitis spp); banana (Musa spp); orange (Citrus sinensis (L.) Osbeck); papaya (Carica papaya L.), and coconut (Cocos nucifera L.).

\section{RESULTS AND DISCUSSION}

\section{Implications of the protection law}

It is understood that the way cultivars are obtained from crosses between endogamic lines allows for "natural patenting" of hybrid seed. In this case, the cultivar is protected, because only the original cross between the genitors will originate the same genetic constitution, and utilization of seed from the first crop for a new planting will result in heterogenic plants that produce little, due to genetic segregation and reduction in heterosis (Hallauer and Sears, 1973; Good and Hallauer, 1977; Hallauer et al., 1981).

However, when the variety is autogamous and has commercial value, its descendants can be used continuously for new plantings (Joshi, 1979; Fehr, 1987). It is therefore not unexpected that species that give rise to hybrids provoke greater interest by private institutions, which spend large sums of money for the development of new cultivars, since good results provide an adequate financial return (Carraro, 2005; Bôas, 2008). On the other hand, the public sector has an essential function; since it does not contemplate profit per se, it can invest in the genetic improvement of species that produce seeds that can be used for future harvests, without economic losses for producers or consumers (Freitas, 2006).

For species that permit replanting without production loss, the investment in research is "lost", according to Araújo (2010). He indicated that from the point of view of the financer of plant variety development, by the time the cultivar is recommended for market, even though there is an initial income from the sale of seeds, the financial return is insufficient to at least repay the cost of the research. Therefore, because of economic considerations, there is very little private sector interest in developing varieties that produce reusable seeds. The perspectives for profit are greatly reduced; the private research that is currently conducted is an exception to the rule.

Consequently, knowing that the factors that stimulate private companies to invest in plant breeding are the economic importance of a given culture and the financial return from investments, cultivar protection is a mechanism that favors investment in species that even though they can be replanted from the first-generation seeds, it becomes illegal to utilize descendants for successive plantings.

Obviously, the existence of protection per se does not guarantee that investment by the private sector will increase for species that allow replanting without loss of production. Nevertheless, from a social point of view, it is a condition sine qua non that this new concept be valorized and produces the desired results, advancing Brazilian agriculture to ever higher levels in the participation in the gross national product (GNP). Without this evolution, certainly the current situation will continue, without the necessary contribution of the private sector to species that are not cultivated in large tracts, but that are essential for family agriculture, 
where field labor is needed and valued, reducing the undesirable effects of populations that have become excessively concentrated in urban centers.

From this point of view, with adequate protection in place and improvements in the relevant legislation, certainly profitable options will become available so that the private sector can contribute to the progress of Brazilian agriculture during the 21 st century.

Another impediment to the growth of Brazilian agriculture is restrictions for the interchange of genetic material. Whether ostensive or veiled, restrictions occur that make this interchange quite difficult between local institutions and also with foreign entities. The Cultivar Protection Law (Law No. 9456/97, regulated by Decree 2.366/97) introduced the institution of property rights, producing the legal framework for the registration of genetic patrimony, with the intention to facilitate the interchange of genetic material and, thereby the genetic enrichment of Brazilian agriculture, as well as to allow the importation of commercial seed and assure, as a counterpart, that Brazil can also export this type of material.

It is presumed that someone who has legal rights for a cultivar will not allow seeds of this protected material to be offered overseas for commercial production or for research without financial return. Consequently, with the Cultivar Protection Law in place, import and export of commercial seeds will be stimulated, since cultivar owner's rights are protected.

Interchange of genetic material is necessary for research and is of fundamental importance for the widening of the genetic base of the species that compose the Brazilian diet. Among these crops, many are not originally from Brazil, but were introduced into the country and adapted to the new edaphoclimatic conditions. These crops include rice, dry beans, corn, wheat, soybeans, and most of the fruits and vegetables. Therefore, Brazilian agriculture has benefitted from interchange of germplasm of various plant species that provided the country with food and fiber, material for research and new cultivars that are more productive and that have other desirable characteristics (EMBRAPA, 2010).

Nevertheless, it is important to realize that this interchange occurs for manipulated cultivars, that is genetic material that has been developed through man's interference. Unfortunately, there are no restrictions for the interchange of "original" genetic material, which are part of the biodiversity of the country, in the case of Brazil, the most diverse in the world. This brings up the urgent necessity to regulate by law the protection of this resource against international pirating.

It is understood that the Cultivar Protection Law in Brazil was basically drawn up as part of the globalization of the economy and as a consequence of international treaties. In the USA, as well as in Europe, cultivar protection laws promoted an increase in private investments, with the opening of new plant breeding and seed companies (Butler and Marion, 1985; Nodari and Guerra, 2001). Nevertheless, in the case of Brazil, according to Araújo (2010), there was a strong movement towards the acquisition of local companies by multinational companies. Research on biotechnology, especially that involving genetic engineering, is high in cost and therefore only viable for companies that have considerable capital and (obviously) advanced technology. As these multinationals rapidly develop their research and create these new technologies, they will take over larger proportions of the Brazilian market, reducing the space occupied by local companies.

Finally, there is a preoccupation with the reductions in the genetic patrimony of Brazilian agriculture through genetic erosion, in theory motivated by the cultivar protection system, the effect of which is to reduce the number of cultivated species and decrease genetic variability, provoked by the intense breeding efforts. 
According to Araújo (2010), there do not appear to be reasons for increasing that this will happen, since the risk of genetic base narrowing is only valid for commercial species, and the maintenance of genetic diversity of these species is actually a priority of the research institutions. If it is true that it is not interesting for a country to allow homogenization of its genetic patrimony, for reasons that are obvious, it is no less true that this risk of erosion is more due to deficient public policies directed towards the preservation of this patrimony, a lack of knowledge about this patrimony, and a prospective vision from a genetic viewpoint, than the application of cultivar protection laws, which will have relatively limited action in this area. Even when we examine the genetic stock of commercial species, it is not apparent how a protection law would cause such an effect, compared to a complete lack of regulation of public research that considers the country's genetic patrimony.

Finally, it is useful to emphasize that after the implementation of the Cultivar Protection Law, there have been restrictions (veiled or ostensive) in the interchange of germplasm between local institutions, which is not a positive situation for the progress of plant breeding programs in Brazil. On the contrary, the programs should have facilities for obtaining access to the material in national germplasm banks, in order to favor the continued advance of Brazilian agribusiness.

\section{Registrations}

Overall, 24,000 registrations have been made, involving 4136 different species. We found 7262 registrations for the 27 species that we investigated; though the species that we investigated account for only $0.65 \%$ of the registered species, they account for $30 \%$ of the existing registrations. This demonstrates the agricultural importance of the species that we selected for this study. Among these 7262 registrations, 5308 were made by private institutions, 1549 by public institutions, 35 by public-private partnerships, and 370 by unidentified institutions (cultivars registered, but the maintainer did not identify itself); this means that $73.1 \%$ of the registrations are private property and only $21.3 \%$ belong to public institutions (Figure 1).

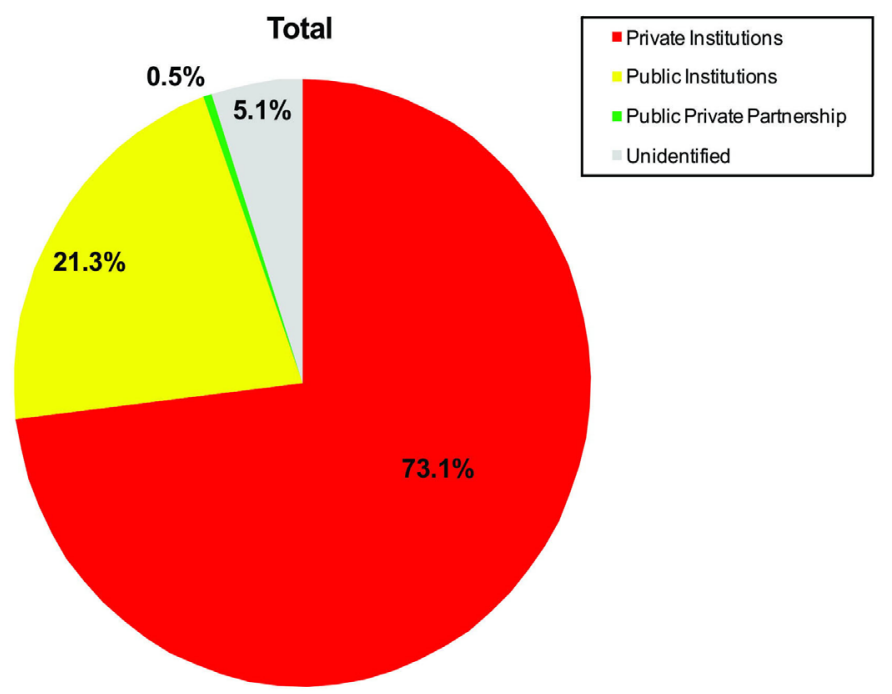

Figure 1. Proportion of registrations according to the nature of the obtainer for the period from 1998 to 2010. 
Among the private registrations, almost $50 \%$ were obtained by foreign companies; five multinationals - Monsanto, Sakata, Dupont, Syngenta, and Dow AgroSciences registered 2042 cultivars (including the main local companies acquired by these multinationals), accounting for approximately $40 \%$ of all private registrations. This fact demonstrates the domination that these large foreign companies have of the local seed market.

Among public registrations, Embrapa participated in or completely developed 788, accounting for $50.97 \%$ of the total. Universities and other academic institutions made 138 registrations, equivalent to only $8.93 \%$. The rest are held by 21 other research and research financing institutions.

The academic institutions that made registrations are: Universidade Estadual do Norte Fluminense Darcy Ribeiro (UENF), Universidade Federal de Lavras (UFLA), Universidade Federal de São Carlos (UFSCar), Universidade Federal de Uberlândia (UFU), Universidade Federal de Viçosa (UFV), Universidade de Brasília (UNB), Universidade Federal do Tocantins (UFT), Instituto Centro de Ensino Tecnológico (CENTEC), Fundação Universidade de Passo Fundo (UPF), Universidade Federal de Santa Catarina (UFSC), Universidade Federal do Rio Grande do Sul (UFRGS), and Universidade Tecnológica Federal do Paraná (UTFPR).

These teaching institutions are distributed geographically as follows: five in the southeast, two in the central-west, one in the north and four in the southern part of the country. There is therefore a concentration of development of products of agricultural research in the southeastern and southern regions of Brazil. This fact can be explained by the pioneering of these regions in agriculture development research.

The public-private partnerships made 35 registrations: 31 of soybeans, three of banana, and one of rice. These partnerships involved 12 institutions: Metropolitana Incorporações e Locação de Bens Ltda.; Instituto Rio Grandense do Arroz; Fundação de Apoio à Pesquisa Agropecuária de Mato Grosso (Fundação MT); Unisoja S/A; Tropical Melhoramento e Genética Ltda.; Empresa Brasileira de Pesquisa Agropecuária (Embrapa); Empresa de Pesquisas Agropecuária de Minas Gerais (EPAMIG); BR Genética Ltda.; Multiplanta Tecnologia Vegetal Ltda.; Agropecuária Boa Fé Ltda.; Cooperativa Agrícola Mista Iraí Ltda. (COPAMIL), and Associação dos Produtores de Sementes e Mudas do Estado de Minas Gerais (APSEMG).

Figure 2, in which we grouped the species into cereals, legumes, vegetables, fruits, and others, represented by the letters A, B, C, D, and E, respectively, revealed differences in the magnitude of registrations. Group A had a mean of 393 registrations, with 351 in group B, 360 in group C, 77 in group D, and 162 in group E. The cereals had the highest mean, followed by the vegetables, legumes, "others", and fruits.

The number of registrations by species in group A included corn with 1605 registrations ( $87.23 \%$ by the private sector); rice, with 237 registrations ( $74.26 \%$ by the public sector); sorghum, with 228 registrations ( $71.5 \%$ by the private sector); wheat, with 195 registrations ( $56.41 \%$ by the public sector); oats, with 56 ( $57.14 \%$ by the public sector), and barley, with 39 registrations $(61.54 \%$ by the public sector).

In a pragmatic analysis, we concluded that corn and sorghum attracted the most attention from private institutions, because they are sold as hybrids and therefore do not need official protection. Corn had by far the most registrations; in comparison with sorghum, it had $703.9 \%$ as many registrations. This large difference is due to the expected economic return. The other crops had more involvement of the public sector, as expected, because of the mode of reproduction, since the seeds can be saved for the following season, which reduces the interest of the public sector in terms of investments. 
A

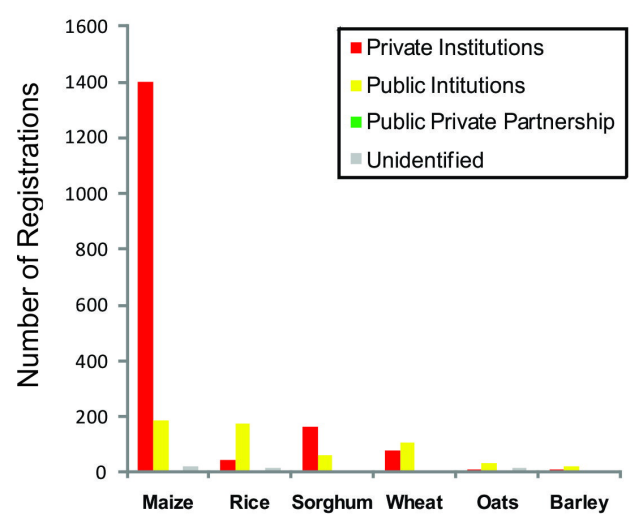

C

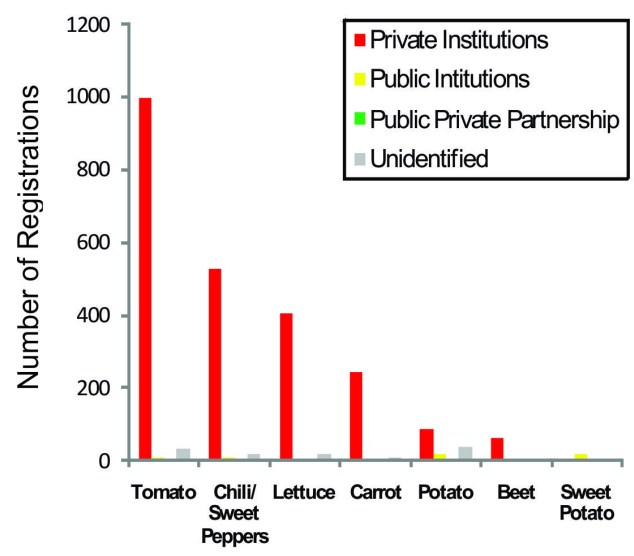

B
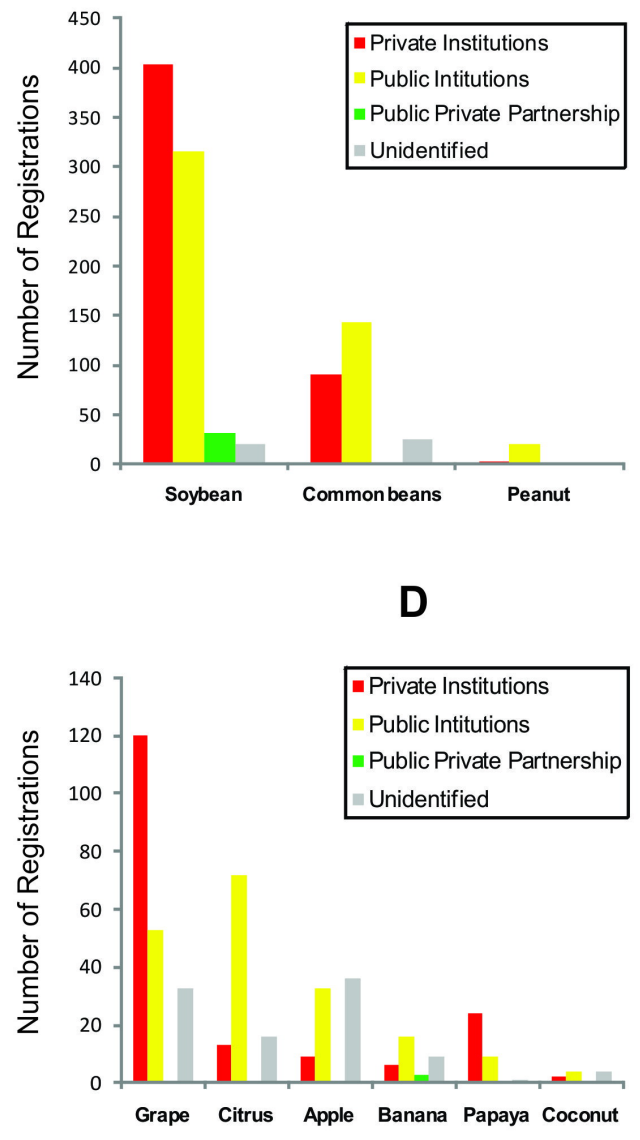

E

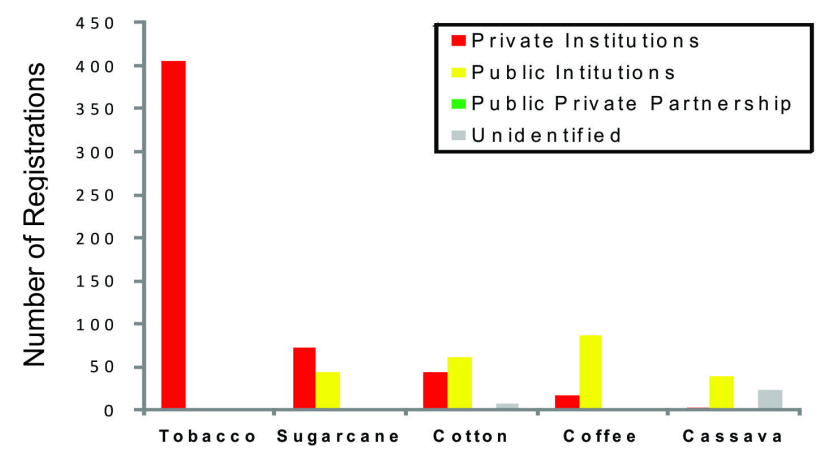

Figure 2. Histograms showing the number of registrations by type of institution from 1998 to 2010. A. Cereals. B. Legumes. C. Vegetables. D. Fruits. E. Others. 
In group B, soybeans had 771 registrations ( $52.40 \%$ by the private sector); common beans had 259 (55.6\% by the public sector), and peanuts had 23 registrations ( $86.96 \%$ by the public sector). This shows that soybeans are an exception to what we have found until now. Even though seeds from producing plants can be used for new plantings, the private sector still maintains interest because of the high economic value of this crop. Common beans were also valued by private institutions; however, less than by the public sector. Peanuts were only registered by public institutions and there were few registrations.

Common beans are a classic example of self-perpetuating crops. Discounting unidentified registering entities, private companies were responsible for $38.46 \%$ of the registrations, while the public sector accounted for $61.53 \%$. This confirms the conclusions of Matos et al. (2007), who reported that Phaseolus vulgaris genetic improvement programs in Brazil are predominantly concentrated in public institutions. Common beans are a Brazilian dietary staple; the main interest by the private sector occurred from 1998 to 2006, especially involving FT Pesquisas e Sementes Ltda., Sementes Sakama Ltda., Syngenta Seeds Ltda., and Monsoy Ltda.

In group $\mathrm{C}$, tomatoes were the most valued crop, with 1044 registrations $(95.69 \%$ by the private sector); Capsicum spp, had 557 registrations ( $94.98 \%$ by the private sector); lettuce had 427 registrations ( $95.1 \%$ by the private sector); carrots had 258 registrations $(94.96 \%$ by private companies); potatoes had 149 registrations (59.73\% by the private sector); beets had 68 registrations ( $94.12 \%$ by the private sector), and sweet potatoes had 18 registrations ( $100 \%$ by the public sector).

It is clear that the private sector has dominated in the development of vegetable cultivars, almost to the exclusion of public institutions, except for sweet potatoes, which were only developed by the public sector. The large number of registrations for this group is due to the necessity of the producer to buy new seeds every planting season; these species require highly specialized techniques for reproduction and are produced as hybrids; therefore, they do not need protection. Also, considering the number of registrations that were recorded, one can conclude that this segment of the market is profitable.

The results for group D were: grapes, 206 registrations ( $58.25 \%$ by the private sector); oranges, 101 registrations $(71.29 \%$ by the public sector); apple, 78 registrations $(42.31 \%$ by the public sector); banana, 34 registrations ( $47.1 \%$ by the public sector); papaya, 34 registrations $(70.59 \%$ by the private sector), and coconut, 10 registrations ( $40 \%$ by the public sector). Grapes and papaya attracted more attention from private companies; however, the public sector has also been developing cultivars of these crops, though with little emphasis. The remaining species attracted more attention from public than from private entities; nevertheless, many cultivars of apple, banana and coconut are registered without identification of the registrant, indicating less interest in general. Grapes and papaya, the species of this group with greatest market value, attracted the most interest from private companies. This group had the fewest registrations, probably because these crops require a long time for development of new cultivars, as they are perennial or semi-perennial; therefore, it takes longer for companies to receive a return for their investment.

Group E includes tobacco, 405 registrations (100\% by the private sector); sugarcane, 119 registrations $(61.34 \%$ by the private sector); cotton, 115 registrations ( $54 \%$ by the public sector); coffee, 105 registrations ( $82.86 \%$ by the public sector), and cassava, 66 registrations ( $60.61 \%$ by the public sector). In this group, tobacco cultivar development is completely controlled by the private sector, and it included the largest number of cultivars in this group. Sug- 
arcane, even though it is reproduced vegetatively, still attracted a lot of attention from private entities, quite likely because of the potential for profit. The other crops have attracted considerable attention from the public sector, especially coffee, because of its great socio-economic importance for the country.

Figure 3 indicates the number of registrations per crop per year, allowing us to observe variations in the number each year for each species.

A

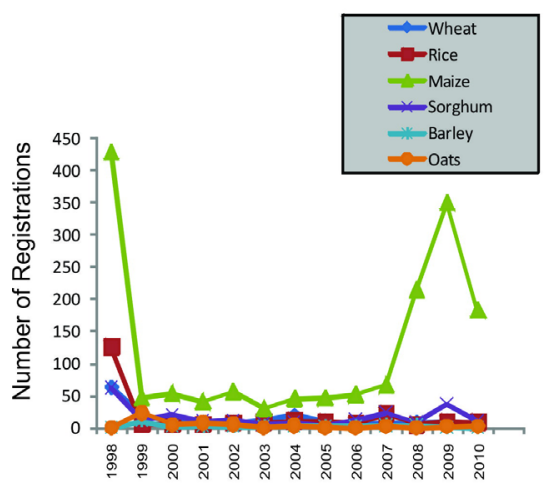

C

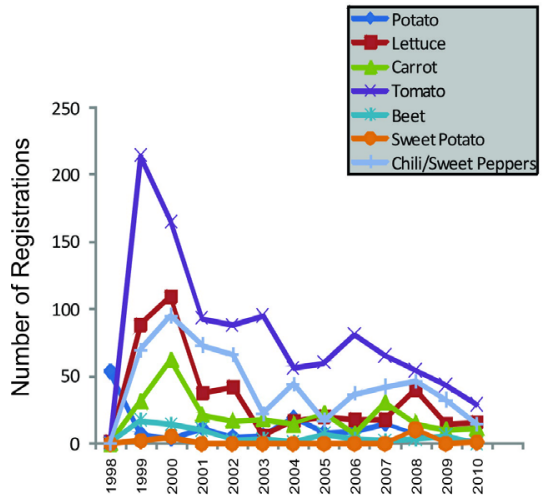

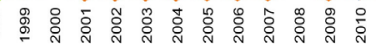

B
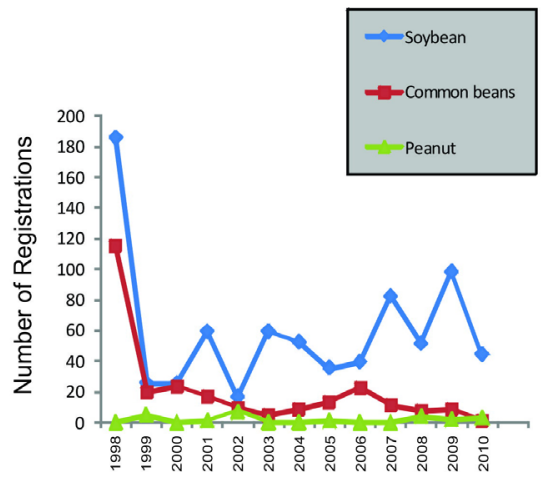

D

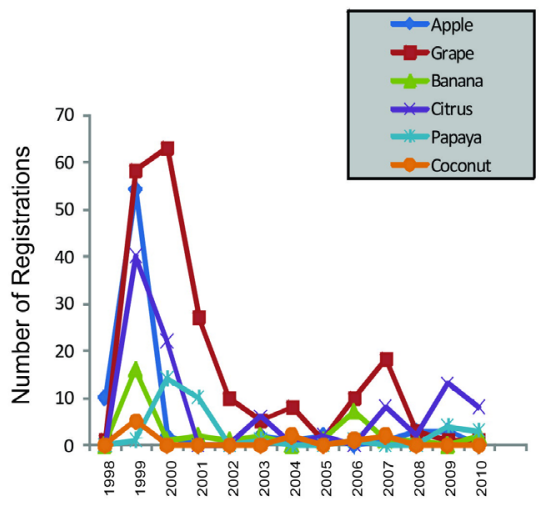

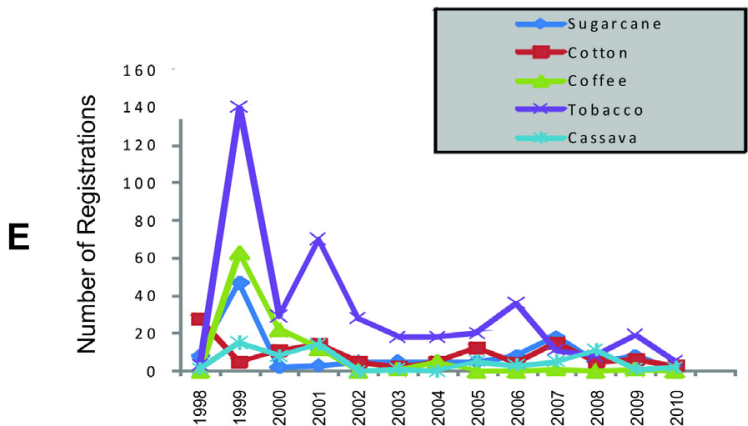

Figure 3. Figures that show the dynamics of the number of registrations from 1998 to 2010. A. Cereals. B. Legumes. C. Vegetables. D. Fruits. E. Others. 


\section{Protections}

The national system for the protection of cultivars includes 1405 protections for 63 species. In the case of the 27 species that we selected for our study, there are 1053 protections, which accounts for $75 \%$ of the total, demonstrating that our choice of species was correct.

Among the protections that were identified, 564 were obtained by private entities, 451 by public institutions and 38 from partnerships between the two. Private initiative detains $53.56 \%$ of the protections and the public sector, $42.83 \%$ (Figure 4 ).

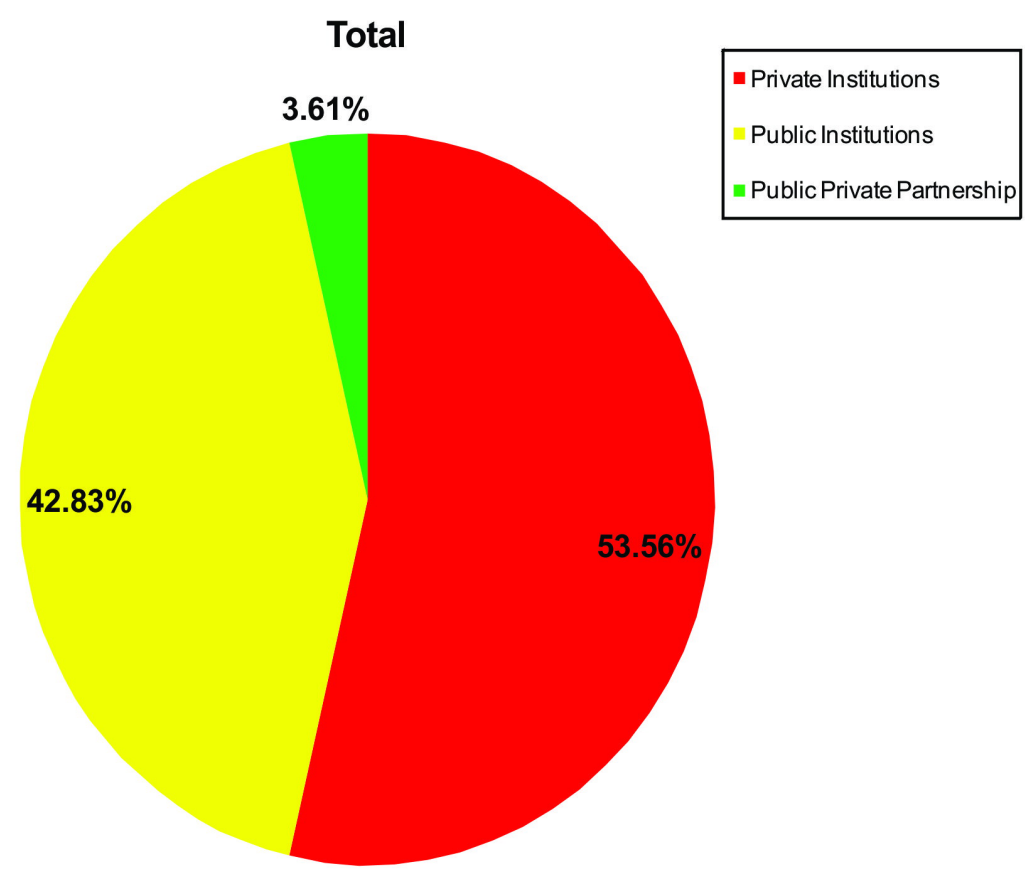

Figure 4. Proportion of protections according to the nature of the obtainer from 1998 to 2010.

Among the protections requested by the private sector, $61.35 \%$ were made by foreign companies. Five companies (Monsanto, Dow Agrocience, Dupont, Sakata, and Syngenta) retain $31.56 \%$ of the private company protections, $21.63 \%$ by Monsanto alone (including the companies that it acquired). This clearly demonstrates that the private sector, mainly the large multinational companies, practically control the Brazilian seed market, a fact that is of concern for the food security of the country and a paradox for the Magna Carta, which established via constitutional amendment 64, the recognition of the right of access to food. There are 26 public institutions that hold protections, of which eight are universities. Research institutes were responsible for $78.7 \%$ of the protections, while the universities accounted for $11.1 \%$, and the rest $(10.2 \%)$, were developed by partnerships between institutions. Embrapa (equivalent to 
USDA in the USA) holds 289 exclusive protections and 34 in partnerships, totaling 323 , which corresponds to $71.6 \%$ of the protections maintained by public institutions.

The Brazilian institutions that possess protections are: UFV, UFSCar, Universidade Federal de Alagoas (UFAL), UFLA, UFU, UFPR, UFRGS, and Escola Superior de Agricultura "Luiz de Queiroz" (ESALQ-USP). These have the following geographic distribution: five in the southeast, two in the south, and one in northeast Brazil. Again we see a concentration in the south and southeast in the development of agriculture technology.

Public-private partnerships registered 38 protections: soybean (32), rice (3), wheat (2), and oats (1). These partnerships involved 18 institutions: Metropolitana Incorporações e Locação de Bens Ltda.; Instituto Rio Grandense do Arroz; Fundação de Apoio à Pesquisa Agropecuária do Mato Grosso; Unisoja S/A; Tropical Melhoramento e Genética Ltda.; Embrapa; Agência Rural; Centro Tecnológico para a Pesquisa Agropecuária (CTPA); Emater - GO; Associação Goiâna dos Produtores de Sementes (AGROSEM); EPAMIG; Agropecuária Boa Fé Ltda.; COPAMIL; APSEMG; UFV; Cooperativa Agropecuária do Alto Paranaíba Ltda.; Fundação Centro de Experimentação e Pesquisa Fecotrigo, and Fundação Agrária de Pesquisa Agropecuária (FAPA).

Some cultivars were developed overseas and are protected in Brazil. Potatoes, soybeans, cotton, lettuce, apples, rice, and barley include 113 foreign-origin cultivars, comprising $10.73 \%$ of the protections; potatoes stood out, accounting for $85.1 \%$ of these protections. The other species did not have foreign cultivars protected in Brazil. Nevertheless, if we consider the 63 species with 1405 protections registered with MAPA, the number of foreign cultivars protected here increases to 406 , which represents $28.9 \%$ of the number of protections. This scenario reveals the influence of the protection laws on the flow of new cultivars from other countries into Brazil, after the rights of the entity that developed them were guaranteed. This facility has created a problem for the Brazilian public sector, which has less capital and is not competitive, principally because the multinationals establish partnerships with producers in areas that are edafoclimatically favorable, not allowing these producers to associate with any other private companies, or even with public institutions.

Figure 5, divided into cereals (A), legumes (B), vegetables (C), fruits (D), and others (E), revealed differences in numbers of protections between the groups. Group A had a mean of 41.5 , group B had 168, group C had 14.7, group D had 5.3, and group E had 33. Though legumes seemed especially favored, this was basically due to soybeans, which alone accounted for $92.66 \%$ of the protections in group B.

The number of protections, in decreasing order in group A were: wheat, 94 protections $(52.13 \%$ by the private sector), rice, 66 protections ( $63.64 \%$ by the public sector); corn, 47 protections $(87.23 \%$ by the public sector); sorghum, 25 protections ( $92 \%$ by the public sector); barley, 10 protections ( $80 \%$ by the public sector), and oats, with seven protections $(71.43 \%$ by the public sector).

In group B, soybeans had 467 protections ( $57 \%$ by the private sector); common beans, 37 protections ( $78.4 \%$ by the public sector), and peanuts had no protections registered. These data demonstrate that the proportion between the public and private sectors as regards registering soybean cultivars was maintained after implementation of the protection law. In any case, we cannot ignore that the great increase in magnitude of the number of protections is due to the financial return from this crop, which is cultivated on a large 
A

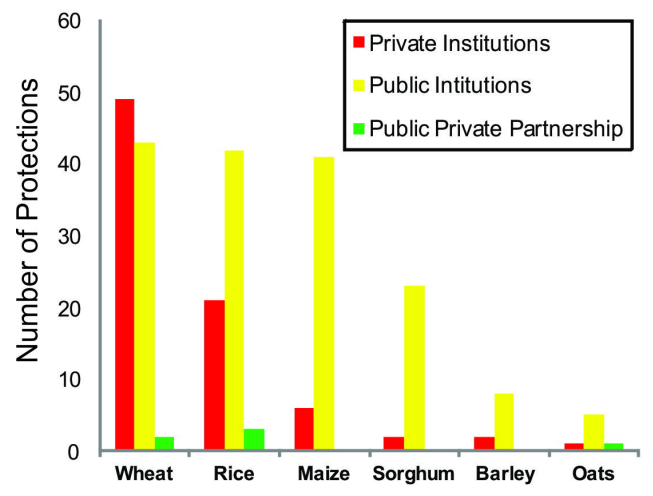

C

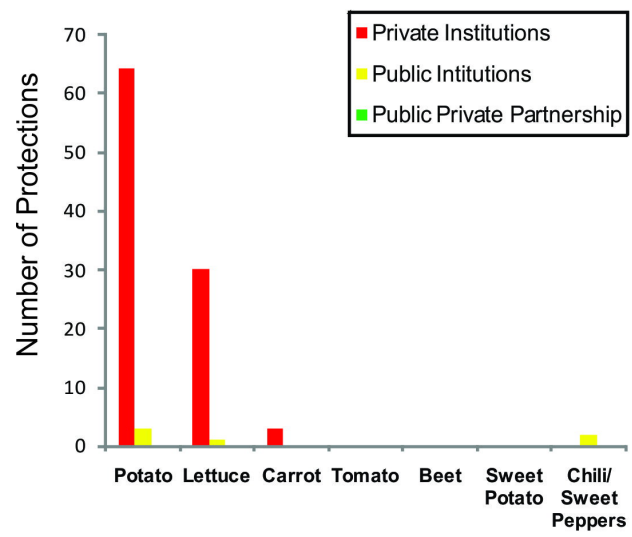

B

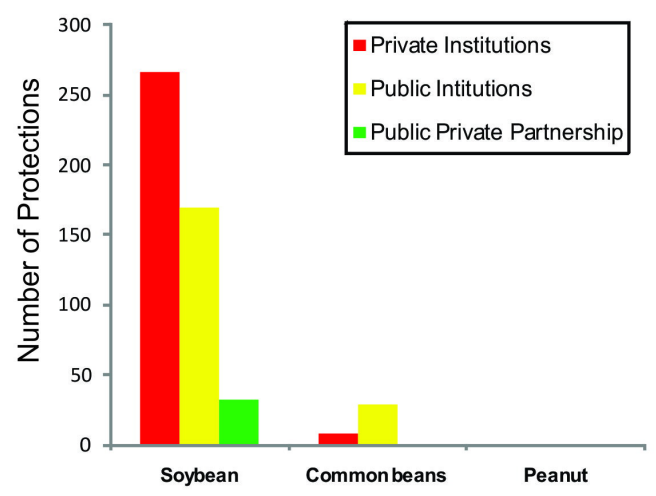

D

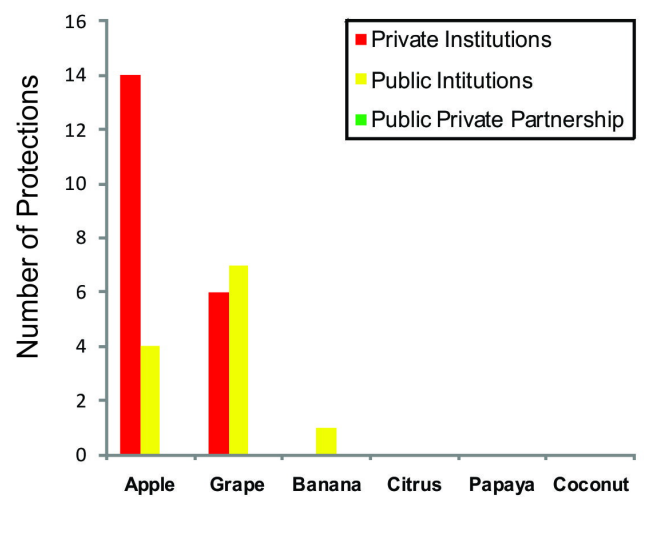

E

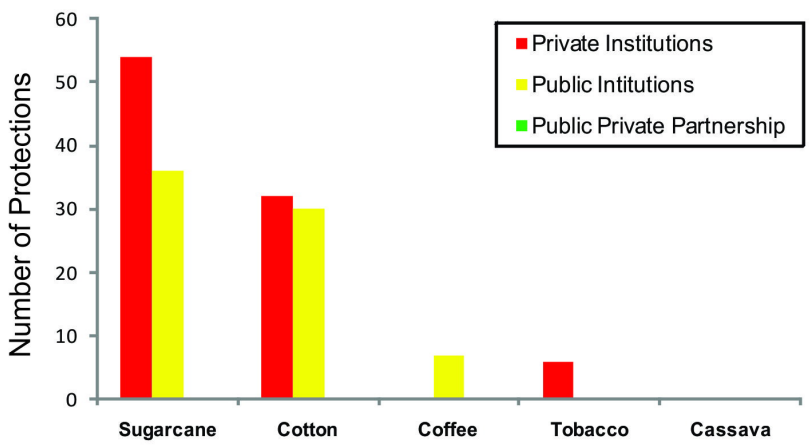

Figura 5. Histograms showing the number of protections by type of institution from 1998 to 2010. A. Cereals. B. Legumes. C. Vegetables. D. Fruits. E. Others. 
scale and accounts for $26.6 \%$ of the exports of Brazilian agriculture. Common beans also did not have changes in the protection pattern; the public sector continues to be mainly responsible for the production of new cultivars, especially as a product of research on disease resistance. All the cultivars that were registered as protected in 2009 (BRS 9435 Cometa, BRS Estilo and IAC Boreal) have resistance to different races of anthracnose (pathotypes 55, 89, 95, and 453). Along with this characteristic, cultivar BRS Cometa is resistant to common mosaic virus, has an erect architecture, is resistant to lodging and has an 80-day cycle. Cultivar BRS Estilo has erect growth and is high producing, both during rainy and dry seasons. Cultivar IAC Boreal has excellent quality grains, is high yielding, has erect growth and an 80-day cycle (Chiorato et al., 2008; Faria et al., 2008; Pereira et al., 2010).

Group C includes: potato, 67 protections ( $95.52 \%$ by the private sector); lettuce, 31 protections $(96.8 \%$ by the private sector); carrots, three protections $(100 \%$ by the private sector); Capsicum spp, two public protections; while tomatoes, beets and sweet potatoes had no protections registered. Therefore, the vegetables were not affected by the cultivar protection law, since the few protected cultivars belonged to private companies. So we can see that the mode of propagation of the species of this group is sufficient to maintain the exclusivity of those that produce them. Even with the possibility of financial return, supported by this new law, the public institutions are not counterbalancing the market in this segment, leaving these cultures to the control of private companies. It is therefore necessary to establish policies that drive the public sector to become more aggressive in the protection of these species, which have an important role in the food security of the nation; this would also help family agriculture, which has a strong social impact on the employment of idle labor that otherwise accumulates in urban centers, in order to minimize the current levels of social exclusion in rural regions.

The results for group D were: apple, 18 protections $(77.78 \%$ by the private sector); grapes, 13 protections $(53.85 \%$ by the public sector); banana, one public protection; while oranges, papaya and coconuts had no registered protections. We saw some changes in apples. The interest by private entities increased from $11.54 \%$ registrations to $77.78 \%$ protections. Grapes had $25.73 \%$ of the cultivars registered by public institutions and $53.85 \%$ of the cultivars protected by the public sector. For the other cultures, changes were not seen in the number of registrations/protections, since banana had only one, while oranges, papaya and coconut had none.

Group E included sugarcane, 90 protections ( $60 \%$ by the private sector); cotton, 62 protections $(51.61 \%$ by the private sector); coffee, seven protections $(100 \%$ by the public sector); tobacco, six protections ( $100 \%$ by the private sector), and cassava had no protections. These cultures were also influenced by the cultivar protection law. Cotton had $54 \%$ of the cultivars registered by public institutions; however, among the protections, this number was inverted, changing to $51.61 \%$ of the cultivars retained by the private sector. In the rest the proportions remained the same; cassava had no protections.

Figure 6 shows the variations in protections obtained each year for each crop, allowing a better comprehension of the variations for the 27 crops that we selected for the present study. 
A

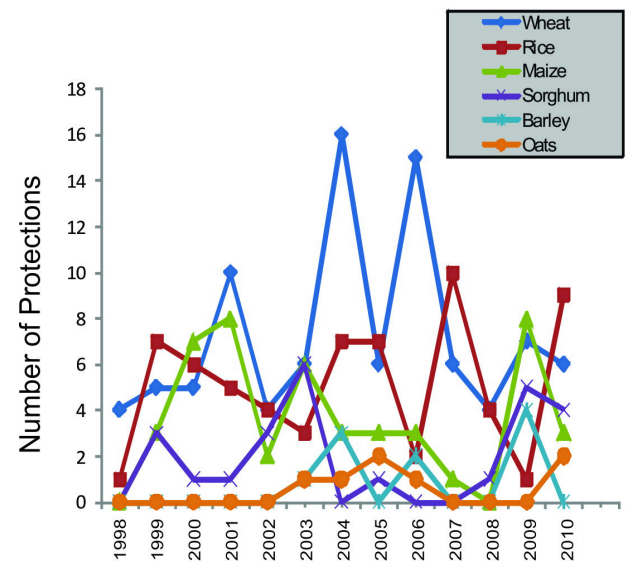

C

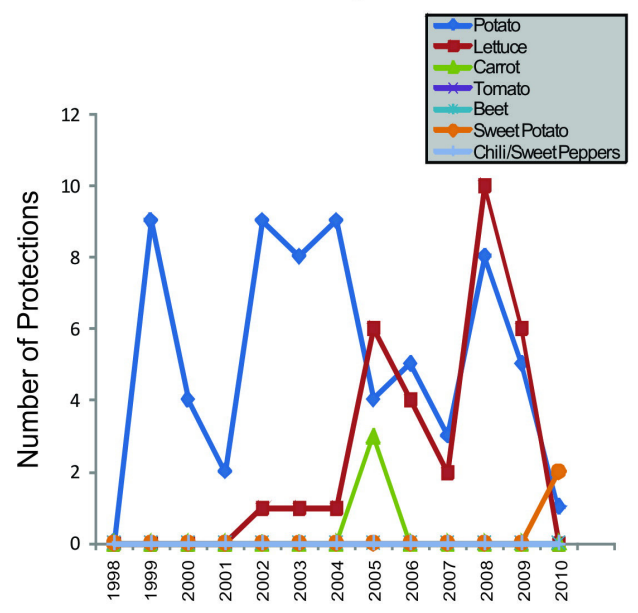

B
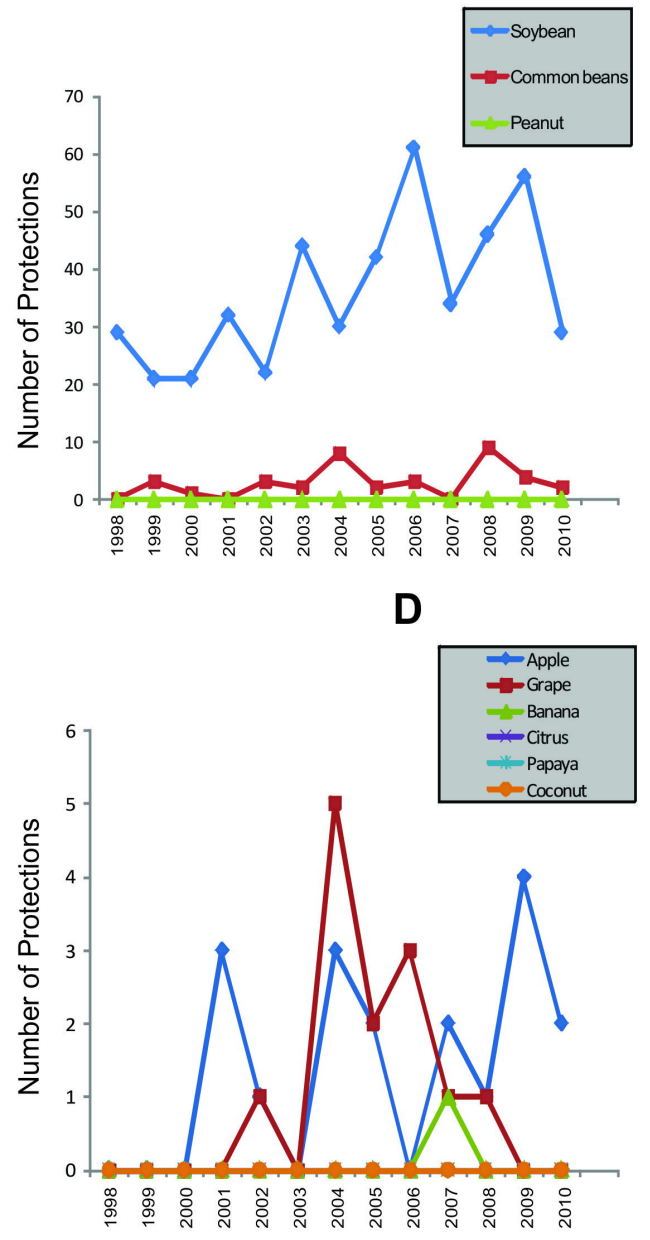

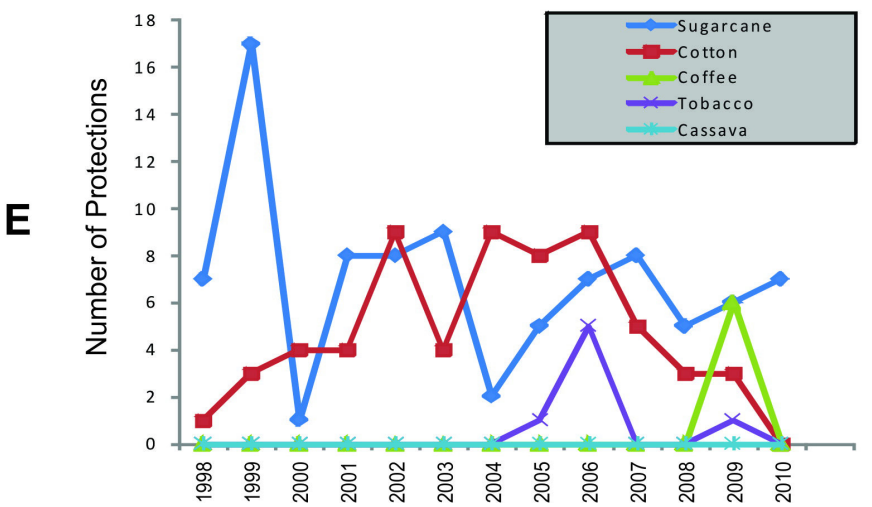

Figure 6. Figures showing the variation in the number of protections for 27 plant species from 1998 to 2010 . 


\section{CONCLUSIONS AND PERSPECTIVES}

Private companies possess $73.1 \%$ of the registrations and $53.6 \%$ of the protections for the 27 crops we included in our study. This confirms the domination by the private sector. Public institutions have $21.3 \%$ of the registrations; however, they have $42.8 \%$ of the existing protections, which demonstrates a significant advance compared to private enterprise, demonstrating that the cultivar-protection law provides incentive for public research.

Public-private partnerships have contributed little to the production of new cultivars. The percentage participation of these partnerships in registrations and protections was only 0.5 and $3.61 \%$, respectively. This demonstrates the lack of integration between public and private sectors, which should become more involved, along with the conquest of technological advances. Nevertheless, partnerships between public institutions accounted for $12 \%$ of the public registrations and $22 \%$ of the public protections, indicating that the modus operandis of interactions works, even though timidly, between Brazilian public institutions, which constitute partnerships and convergence networks in plant breeding programs, especially involving Embrapa.

We found that $50 \%$ of the registrations and $33 \%$ of the protections from these partnerships involved Embrapa. Based on these proportions, and the fact that Embrapa is the largest public holder of registrations (51\%) and of protections (72\%), we can see that Embrapa is the institution with the largest number of cultivars developed for the crops that we studied. This brings up a question; does this activity by Embrapa contribute directly to the low number of existing partnerships?

This is because while Embrapa is guardian and caretaker of the largest Brazilian germplasm bank, it also develops cultivars. Having both these attributions results in conflicts of interest, which can generate various types of consequences for the integration between sectors, which should include interchange of germplasm for producing and protecting new cultivars?

Araújo (2009) examined the correspondence sent by the Associação Nacional dos Produtores de Sementes de Gramíneas e Leguminosas Forrageiras (ANPROSEN) to MAPA concerning the difficulty in obtaining germplasm from Embrapa. ANPROSEN describes the behavior of Embrapa related to the use and availability of germplasm, showing a change in attitude, comparing the periods before and after implementation of the Cultivar Protection Law (Law No. 9456, of April 25, 1997) and the time lapse that followed the sanctioning of this law.

According to this association, before this cultivar protection law was implemented, Embrapa cooperated strongly with universities, institutes and public research companies, interchanging genetic material and promoting partnerships, which resulted in new cultivars offered to the public. After the cultivar protection law took effect in 1997, Embrapa changed its policies of liberating germplasm, placing it under strict control, liberating it only for joint projects with private research companies and with research foundations that Embrapa itself had constituted, now found in various regions of Brazil.

There is currently too much bureaucracy and impediments to allow exchanges within the country, to the point that it are easier to obtain material through international exchange. This fact is corroborated by the number of exotic species currently produced within the country and the enrichment and the importance of the national germplasm banks. On the other hand, we see only a small participation of partnerships between Brazilian institutions, in the development of new cultivars. 
Therefore, it can be seen that public-private partnerships have not contributed much to the development of Brazilian agriculture, in terms of producing new cultivars. The private sector is mainly responsible for this growth. In any case, public institutions have become very effective, beginning to counterbalance this domination. This principally involves Embrapa, which has been demonstrably efficient in the development of new cultivars.

Comparing data on registrations and protections, among the cereals, private companies increased their interest, as the percentage of cultivars that they registered, which was $41.03 \%$, increased to $52.13 \%$ of the protections. In the case of rice, the percentage of the cultivars registered by the private sector, which was $18.57 \%$, increased to $31.82 \%$ of the protections. Corn had only $11.52 \%$ of the public registrations; this increased to $87.23 \%$ of the protections. For sorghum, public entities controlled $26.32 \%$ of the registered cultivars, which increased to $92 \%$ of the protections. However, oats and barley maintained a higher proportion of cultivars developed by public institutions. We conclude that the possibility of protection increased private investments in developing wheat and rice cultivars, while public entities invested more in corn and sorghum.

Examining the current situation, both public and private sectors pay little attention to developing new cultivars of various key crops, including peanuts, coconuts, and sweet potatoes. The private sector is even less interested in these crops, except for a few cultivars of coconut. No private sector protections were made for peanuts and sweet potatoes. Consequently, some crops of relevant national interest should be considered by government public policies, in order to provide genetic material that will help low income families grow products that have nutraceutic value and are profitable. This would also help overcome nutritional deficiencies, especially in less developed areas, such as northeast Brazil.

\section{REFERENCES}

Araújo JC (2009). Estudo sobre Documento Encaminhado pela Associação Nacional dos Produtores de Sementes de Gramíneas e Leguminosas Forrageiras - ANPROSEN, Acerca de Dificuldades de Obtenção de Germoplasma Junto à Embrapa. Câmara dos Deputados, Consultoria Legislativa, Brasília, 13.

Araújo JC (2010). A Lei de Proteção de Cultivares: Análise de sua Formulação e Conteúdo. $1^{\mathrm{a}}$ ed. Edições Câmara, Brasília.

Bôas HDCV (2008). A Empresa Pública de Pesquisa e os Marcos Legais na Indústria de Sementes. Doctoral thesis, Universidade Federal de Pelotas, Pelotas.

Butler LJ and Marion BW (1985). The Impacts of Patent Protection on the US Seed Industry and Public Plant Breeding. Monograph, University of Wisconsin, Madison.

Carraro IM (2005). A Empresa de Sementes no Ambiente de Proteção de Cultivares no Brasil. Doctoral thesis, Universidade Federal de Pelotas, Pelotas.

Chiorato AF, Carbonell SAM, Ito MF and Benchimol LL (2008). Cultivar release-IAC-Boreal and IAC-Harmonia: common bean cultivars with striped grains. Crop Breed. Appl. Biotechnol. 8: 170-173.

CONAB (2010). Companhia Nacional de Abastecimento, Levantamento de Safra. Available at [http://www.conab.gov.br/ conteudos.php?a=1253\&t=2]. Accessed September 14, 2010.

EMBRAPA (2010). Empresa Brasileira de Pesquisa Agropecuária. Intercâmbio de Recursos Genéticos Vegetais. Plataforma Nacional de Recursos Genéticos. Available at [http://plataformarg.cenargen.embrapa.br/pnrg/redetransversal/projetos-componentes/pc4-intercambio-de-recursos-geneticos-vegetais]. Accessed September 25, 2010.

Faria LC, Del-Peloso MJ, Melo LC and Costa JGC (2008). BRS Cometa: a carioca common bean cultivar with erect growth habit. Crop Breed. Appl. Biotechnol. 8: 167-169.

Fehr WR (1987). Principles of Cultivar Development, Crop Species. McGraw-Hill, New York.

Freitas AS (2006). O Papel das Instituições Públicas no Desenvolvimento de Novas Variedades de Plantas Cultivadas. Master's thesis, Universidade Federal do Rio Grande do Sul, Porto Alegre.

Good RL and Hallauer AR (1977). Inbreeding depression in maize by selfing and full-sibbing. Crop Sci. 17: $935-340$. 
Hallauer AR and Sears JH (1973). Changes in quantitative traits associated with inbreeding in a synthetic variety of maize. Crop Sci. 13: 327-330.

Hallauer AR, Carena MJ and Miranda FJB (1981). Quantitative Genetics in Maize Breeding. 3rd edn. Iowa State University Press, Ames.

IBGE (2010). Instituto Brasileiro de Geografia e Estatística. Levantamento Sistemático da Produção Agrícola. Available at [http://www.ibge.gov.br/home/estatistica/indicadores/agropecuaria/lspa/default.shtm]. Accessed September 20, 2010.

ISTOÉ Dinheiro (2010). Ninguém Mais Pode Ignorar o Brasil. Revista Semanal de Economia, Finanças, Negócios e Investimentos. Editora Três, São Paulo.

Joshi AF (1979). Breeding methodology for autogamous crops. Indian J. Genet. Plant. Breed. 39: 567-578.

Lourenço C and Lima B (2009). Evolução do Agronegócio Brasileiro, Desafios e Perspectivas. Available at [http://www. eumed.net/cursecon/ecolat/br/09/clbl.htm]. Accessed September 20, 2010.

MAPA (2010). Ministério da Agricultura, Pecuária e Abastecimento. Available at [http://extranet.agricultura.gov.br/php/ proton/cultivarweb/cultivares_registradas.php?]. Accessed August 30, 2010.

Matos JW, Ramalho MAP and Abreu AFB (2007). Trinta e dois anos do programa de melhoramento genético do feijoeiro comum em Minas Gerais. Ciênc. Agr. 31: 1749-1754.

MDIC (2010). Ministério do Desenvolvimento, Indústria e Comércio Exterior. Available at [http://www.desenvolvimento. gov.br/sitio/]. Accessed September 20, 2010.

Nodari RO and Guerra MP (2001). Implicações da Proteção Intelectual na Conservação e Uso dos Recursos Genéticos. In: Anais da 53ª Reunião Anual da Sociedade Brasileira para o Progresso da Ciência, São Paulo, 1-5.

Pereira HS, Melo LC, Faria LC and Del-Peloso MJ (2010). Indicação de cultivares de feijoeiro-comum baseada na avaliação conjunta de diferentes épocas de semeadura. Pesq. Agr. Bras. 45: 571-578.

Pinto RJB (2009). Introdução ao Melhoramento Genético de Plantas. $2^{\mathrm{a}}$ ed. Eduem, Maringá.

Rodrigues R (2006). O Céu é o Limite para o Agronegócio Brasileiro. Conjuntura Econômica, Rio de Janeiro, 14-15.

Tollefson J (2010). The global farm. Nature 466: 554-556.

Wilkinson J (2010). Transformações e perspectivas dos agronegócios brasileiros. Rev. Bras. Zootec. 39: 26-34. 